\title{
denenera-ive Diseases
}

\section{Editor-in-Chief}

R.M. Nitsch, Zurich

Associate Editors

C. Hock, Zurich

P.G. Unschuld, Zurich

M. Polymenidou, Zurich

\section{Editorial Board}

\section{Neurobiology}

Molecular Biology

K. Beyreuther, Heidelberg

\section{Cell Biology}

M. Goedert, Cambridge

T. Iwatsubo, Tokyo

E.H. Koo, San Diego, Calif.

N.K. Robakis, New York, N.Y.

G. Thinakaran, Chicago, Ill.

Official Journal of the

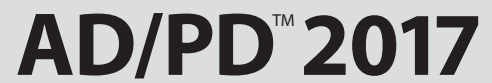

International Conference on Alzheimer's \& Parkinson's Diseases

\section{Animal Models}

J. Shen, Boston, Mass.

Structural Biology

B. Solomon, Tel Aviv

\section{Clinical Research}

Genetics

A. Brice, Paris

L. Lannfelt, Uppsala

W. Le, Shanghai

C. Van Broeckhoven, Antwerpen

Neuropathology

B. Ghetti, Indianapolis, Ind.

C.L. Masters, Melbourne, Vic.

\section{Imaging}

A. Villringer, Berlin

Biological Markers

K. Blennow, Mölndal

J.H. Growdon, Boston, Mass.

Therapy

S.T. DeKosky, Charlottesville, Va.

\section{Drug Discovery}

Pharmaceuticals

A. Fisher, Ness Ziona

B. Schmidt, Darmstadt

H. Soreq, Jerusalem

M. Takeda, Osaka 


\section{Neurn -

No. 1

Original Papers

1 Granulocyte Colony-Stimulating Factor Ameliorates Skeletal Muscle Dysfunction in Amyotrophic Lateral Sclerosis Mice and Improves Proliferation of SOD1-G93A Myoblasts in vitro Rando, A.; Gasco, S.; de la Torre, M. (Zaragoza); García-Redondo, A. (Madrid); Zaragoza, P.; Toivonen, J.M.; Osta, R. (Zaragoza)

14 The Prognostic Role of Obstructive Sleep Apnea at the Onset of Amyotrophic Lateral Sclerosis

Quaranta, V.N.; Carratù, P.; Damiani, M.F.; Dragonieri, S.; Capozzolo, A.; Cassano, A.; Resta, O. (Bari)

22 Novel Blood Biomarkers Are Associated with White Matter Lesions in Fragile X-Associated Tremor/Ataxia Syndrome

Loesch, D.Z.; Annesley, S.J.; Trost, N.; Bui, M.Q.; Lay, S.T.; Storey, E.; De Piazza, S.W.; Sanislav, O.; Francione, L.M.; Hammersley, E.M. (Melbourne, Vic.); Tassone, F. (Sacramento, Calif.); Francis, D.; Fisher, P.R. (Melbourne, Vic.)

31 Differential Progression of Midbrain Atrophy in Parkinsonism: Longitudinal MRI Study

Hwang, M.; Yang, H.; Kim, Y.; Youn, J.; Park, J.; Huh, Y.E.; Kim, H.-T.; Cho, J.W. (Seoul)

44 Brain-Derived Neurotrophic Factor Facilitates Functional Recovery from ALS-Cerebral Spinal Fluid-Induced Neurodegenerative Changes in the NSC-34 Motor Neuron Cell Line

Shruthi, S.; Sumitha, R.; Varghese, A.M.; Ashok, S.;

Chandrasekhar Sagar, B.K.; Sathyaprabha, T.N.; Nalini, A. (Bangalore); Kramer, B.W. (Maastricht); Raju, T.R.; Vijayalakshmi, K.; Alladi, P.A. (Bangalore)

Brief Communications

38 Clinical Impact of ${ }^{123}$ I-loflupane SPECT (DaTscan) in a Movement Disorder Center

Graebner, A.K.; Tarsy, D.; Shih, L.C.; Vanderhorst, V.; Kulkarni, O.; Kaplan, S.; Simon, D.K. (Boston, Mass.)

59 Voltage-Gated Potassium Channel Antibodies in Slow-Progression Motor Neuron Disease

Godani, M. (La Spezia); Zoccarato, M. (Treviso); Beronio, A. (La Spezia); Zuliani, L. (Treviso); Benedetti, L. (La Spezia); Giometto, B. (Treviso); Del Sette, M. (Genova); Raggio, E.; Baldi, R. (La Spezia); Vincent, A. (Oxford)
No. 2-3

Original Papers

63 Visual Hallucination and Pattern of Brain Degeneration in Parkinson's Disease

Lee, W.-W.; Yoon, E.J.; Lee, J.-Y.; Park, S.-W.; Kim, Y.K. (Seoul)

73 Cl-NQTrp Alleviates Tauopathy Symptoms in a Model Organism through the Inhibition of Tau AggregationEngendered Toxicity

Frenkel-Pinter, M.; Tal, S.; Scherzer-Attali, R.; Abu-Hussien, M.; Alyagor, I.; Eisenbaum, T.; Gazit, E.; Segal, D. (Tel Aviv)

83 Cerebrospinal Fluid Progranulin, but Not Serum Progranulin, Is Reduced in GRN-Negative Frontotemporal Dementia Wilke, C. (Tübingen); Gillardon, F. (Biberach an der Riss); Deuschle, C.; Hobert, M.A. (Tübingen); Jansen, I.E. (Tübingen/Amsterdam); Metzger, F.G.; Heutink, P.; Gasser, T.; Maetzler, W.; Blauwendraat, C.; Synofzik, M. (Tübingen)

89 Arterial Stiffness and Cardiovascular Autonomic Dysfunction in Patients with Parkinson's Disease Kim, J.-S.; Lee, S.-H.; Oh, Y.-S.; Park, J.-W.; An, J.-Y.; Choi, H.-S.; Lee, K.-S. (Seoul)

97 Precuneal Thickness and Depression in Parkinson Disease Zanigni, S.; Sambati, L.; Evangelisti, S.; Testa, C.; Calandra-Buonaura, G.; Manners, D.N.; Terlizzi, R.; Poda, R.; Oppi, F.; Lodi, R.; Cortelli, P.; Tonon, C. (Bologna) on behalf of the BoProPark Study Group

103 Identification of Small Peptides in Human Cerebrospinal Fluid upon Amyloid- $\beta$ Degradation

Mizuta, N.; Yanagida, K.; Kodama, T.; Tomonaga, T. (Osaka); Takami, M. (Kizugawa); Oyama, H. (Osaka); Kudo, T. (Toyonaka); Ikeda, M.; Takeda, M.; Tagami, S.; Okochi, M. (Osaka)

110 Environmental and Occupational Exposures and Amyotrophic Lateral Sclerosis in New England

Andrew, A.S. (Hanover, NH); Caller, T.A. (Cheyenne, WY); Tandan, R. (Burlington, VT); Duell, E.J. (Barcelona); Henegan, P.L.; Field, N.C. (Hanover, NH); Bradley, W.G. (Miami, FL); Stommel, E.W. (Hanover, NH)

\section{No. 4-5}

Original Papers

117 Patterns of Eye Movement Impairment Correlate with Regional Brain Atrophy in Neurodegenerative Parkinsonism Vintonyak, O.; Gorges, M.; Müller, H.-P.; Pinkhardt, E.H.; Ludolph, A.C. (Ulm); Huppertz, H.-J. (Zurich); Kassubek, J. (Ulm)

127 Neuropsychiatric Symptoms in Alzheimer Disease, Vascular Dementia, and Mixed Dementia

Anor, C.J.; O'Connor, S.; Saund, A.; Tang-Wai, D.F.; Keren, R.; Tartaglia, M.C. (Toronto, ON)

\section{KARGER}

E-Mail karger@karger.com www.karger.com (c) 2017 S. Karger AG, Basel

Access to full text and tables of contents, including tentative ones for forthcoming issues: www.karger.com/ndd_issues 
135 Home-Based Physical Behavior in Late Stage Parkinson Disease Dementia: Differences between Cognitive Subtypes

Cerff, B. (Tübingen); Maetzler, W. (Tübingen/Kiel); Sulzer, P.; Kampmeyer, M. (Tübingen); Prinzen, J. (The Hague); Hobert, M.A. (Tübingen/Kiel); Blum, D. (Tübingen); van Lummel, R. (The Hague); Del Din, S.

(Newcastle upon Tyne); Gräber, S. (Tübingen); Berg, D. (Tübingen/Kiel); Liepelt-Scarfone, I. (Tübingen)

145 Patterns of Microglial Cell Activation in Alzheimer Disease and Frontotemporal Lobar Degeneration

Taipa, R. (Porto/Minho/Braga/Guimarães); Brochado, P. (Porto); Robinson, A. (Manchester); Reis, I. (Porto); Costa, P. (Minho/Braga/ Guimarães); Mann, D.M. (Manchester); Melo Pires, M. (Porto); Sousa, N. (Minho/Braga/Guimarães)

Review

155 Neurodegeneration and the Cerebellum Samson, M. (Orlando, FL); Claassen, D.O. (Nashville, TN)

Original Papers

166 Increased Risk of Bullous Pemphigoid after First-Ever Stroke: A Population-Based Study

Shen, A.-L. (New Taipei City); Lin, H.-L. (New Taipei City/ Taipei); Lin, H.-C. (Taipei); Tseng, Y.-F. (New Taipei City); Hsu, C.-Y. (Taipei); Chou, C.-Y. (Taichung)

171 Elevated Levels of Selenium Species in Cerebrospinal Fluid of Amyotrophic Lateral Sclerosis Patients with Disease-Associated Gene Mutations

Mandrioli, J. (Modena); Michalke, B. (Neuherberg); Solovyev, N. (Neuherberg/St. Petersburg); Grill, P. (Neuherberg); Violi, F. (Modena); Lunetta, C. (Milan); Conte, A. (Rome); Sansone, V.A. (Milan); Sabatelli, M. (Rome); Vinceti, M. (Modena)

181 A Novel Ataxic Mutant Mouse Line Having Sensory Neuropathy Shows Heavy Iron Deposition in Kidney Hashimoto, H.; Kawabe, T.; Fukuda, T.; Kusakabe, M. (Tokyo)

199 Exploring Neural Efficiency in Multiple Sclerosis Patients during the Symbol Digit Modalities Test: A Functional Magnetic Resonance Imaging Study Fittipaldi-Márquez, M.S.; Cruz-Gómez, Á.J.; Sanchis-Segura, C.; Belenguer, A.; Ávila, C.; Forn, C. (Castellón de la Plana)

208 SLC25A46 Mutations Associated with Autosomal Recessive Cerebellar Ataxia in North African Families

Hammer, M.B.; Ding, J. (Bethesda, MD); Mochel, F. (Paris); Eleuch-Fayache, G. (Tunis); Charles, P.; Coutelier, M. (Paris); Gibbs, J.R. Arepalli, S.K.; Chong, S.B.; Hernandez, D.G.; Majounie, E.; Clipman, S. (Bethesda, MD); Bouhlal, Y. (San Francisco, CA); Nehdi, H. (Tunis); Brice, A. (Paris); Hentati, F. (Tunis); Stevanin, G. (Paris); Amouri, R. (Tunis); Durr, A. (Paris); Singleton, A.B. (Bethesda, MD)

213 Mitochondrial Metabolism in a Large-Animal Model of Huntington Disease: The Hunt for Biomarkers in the Spermatozoa of Presymptomatic Minipigs

Krizova, J.; Stufkova, H.; Rodinova, M. (Prague); Macakova, M.; Bohuslavova, B.; Vidinska, D.; Klima, J.; Ellederova, Z.; Pavlok, A. (Libechov); Howland, D.S. (Princeton, NJ); Zeman, J. (Prague); Motlik, J. (Libechov); Hansikova, H. (Prague)

227 Serum Interleukin-10 Levels Correlate with Cerebrospinal Fluid Amyloid Beta Deposition in Alzheimer Disease Patients D’Anna, L. (Udine/London); Abu-Rumeileh, S. (Udine/Bologna); Fabris, M. Pistis, C. (Udine); Baldi, A. (Venice); Sanvilli, N.; Curcio, F.; Gigli, G.L. (Udine); D’Anna, S. (Venice); Valente, M. (Udine)

\section{No. 6}

Original Paper

235 Frontal Cortex and Hippocampal $\gamma$-Secretase Activating Protein Levels in Prodromal Alzheimer Disease

Perez, S.E.; Nadeem, M.; Malek-Ahmadi, M.H.; He, B.; Mufson, E.J. (Phoenix, AZ)

Review

242 Lessons from Anti-Amyloid- $\beta$ Immunotherapies in Alzheimer Disease: Aiming at a Moving Target

Wang, Y.; Yan, T.; Lu, H.; Yin, W.; Lin, B.; Fan, W.; Zhang, X. (Huzhou); Fernandez-Funez, P. (Duluth, MN)

Original Papers

251 Serum Growth Differentiation Factor 15 in Parkinson Disease Yao, X.; Wang, D.; Zhang, L. (Jinan); Wang, L. (Yantai); Zhao, Z.; Chen, S. Wang, X. (Jinan); Yue, T. (Zibo); Liu, Y. (Jinan)

261 Cerebral Small Vessel Disease Is Associated with Dysregulation in the Ubiquitin Proteasome System and Other Major Cellular Pathways in Specific Brain Regions Ritz, M.-F. (Basel); Grond-Ginsbach, C. (Heidelberg); Fluri, F. (Basel); Kloss, M. (Heidelberg); Tolnay, M.; Peters, N.; Engelter, S.; Lyrer, P. (Basel)

276 Gender Differences of Nonmotor Symptoms Affecting Quality of Life in Parkinson Disease

Yoon, J.-E. (Bundang); Kim, J.S. (Seoul); Jang, W. (Gangneung); Park, J. (Busan); Oh, E. (Daejun); Youn, J.; Park, S.; Cho, J.W. (Seoul)

281 Two Ethnic Clusters with Huntington Disease in Israel: The Case of Mountain Jews and Karaites Zitser, J.; Thaler, A.; Inbar, N.; Gad, A.; Faust-Socher, A. (Tel Aviv); Paleacu, D. (Tel Aviv/Bat Yam); Anca-Herschkovitch, M. (Tel Aviv/Holon); Balash, Y.; Shabtai, H.; Ash, E.L.; Merkin, L. (Tel Aviv); Manor, Y. (Tel Aviv/ Kiryat Ono); Kestenbaum, M.; Bar David, A.; Peretz, C.; Naiman, T.; Bar-Shira, A.; Orr-Urtreger, A. (Tel Aviv); Dangoor, N. (Gedera); Giladi, N. (Tel Aviv/Bat Yam); Gurevich, T. (Tel Aviv)

286 Mild Cognitive Impairment and Progression to Dementia in Progressive Supranuclear Palsy

Pilotto, A. (Brescia/Trescore Balneario); Gazzina, S.; Benussi, A.; Manes, M. Dell'Era, V.; Cristillo, V.; Cosseddu, M.; Turrone, R.; Alberici, A.; Padovani, A.; Borroni, B. (Brescia)

292 ALS-Related Mutant FUS Protein Is Mislocalized to Cytoplasm and Is Recruited into Stress Granules of Fibroblasts from Asymptomatic FUS P525L Mutation Carriers Lo Bello, M.; Di Fini, F.; Notaro, A.; Spataro, R. (Palermo); Conforti, F.L. (Mangone); La Bella, V. (Palermo)

304 Genetic and Pathological Assessment of hnRNPA1, hnRNPA2/ B1, and hnRNPA3 in Familial and Sporadic Amyotrophic Lateral Sclerosis

Fifita, J.A.; Zhang, K.Y.; Galper, J.; Williams, K.L.; McCann, E.P.; Hogan, A.L.; Saunders, N.; Bauer, D.; Tarr, I.S.; Pamphlett, R.; Nicholson, G.A.; Rowe, D.; Yang, S.; Blair, I.P. (Sydney, NSW)

Review

313 Huntington's Disease: Premotor Phase

Ramos, A.R.S.; Garrett, C. (Porto) 
Original Papers

323 Health Status Perspectives in Amyotrophic Lateral Sclerosis Pinto, S. (Lisbon/Umeå); de Carvalho, M. (Lisbon)

330 Subjective Assessment of Sleep in Huntington Disease: Reliability of Sleep Questionnaires Compared to Polysomnography

Piano, C. (Rome/Bologna); Della Marca, G.; Losurdo, A.; Imperatori, C.; Solito, M. (Rome); Calandra-Buonaura, G.; Provini, F.; Cortelli, P. (Bologna); Bentivoglio, A.R. (Rome/Milan)

\section{Acknowledgement to Reviewers}

Suppl. 1

Abstracts

Mechanisms, Clinical Strategies, and Promising Treatments of Neurodegenerative Diseases

13th International Conference AD/PD' ${ }^{\text {TM }}$, Vienna, March-April 2017

Editors: Fisher, A. (Israel); Nitsch, R.M. (Switzerland); Windisch, M. (Austria)
S. Karger

Medical and Scientific Publishers

Basel $\cdot$ Freiburg $\bullet$ Paris $\bullet$ London

New York $\cdot$ Chennai $\cdot$ New Delhi

Bangkok $\cdot$ Beijing $\cdot$ Shanghai $\cdot$ Tokyo $•$

Kuala Lumpur $\cdot$ Singapore $\cdot$ Sydney
Disclaimer

The statements, opinions and data contained in this publication are solely those of the individual authors and contributor and not of the publisher and the editor(s). The appearance of advertisements in the journal is not a warranty, endorsement, or approval of the products or services advertised or of their effectiveness, quality or safety. The publisher and the editor(s) disclaim responsibility for any injury to persons or property resulting from any ideas, methods, instructions or products referred to in the content or advertisements.

Drug Dosage

The authors and the publisher have exerted every effort to en sure that drug selection and dosage set forth in this text are in accord with current recommendations and practice at the time of publication. However, in view of ongoing research, changes in government regulations, and the constant flow of information relating to drug therapy and drug reactions, the reader is urged to check the package insert for each drug for any change in indications and dosage and for added warnings and precautions. This is particularly important when the recommended agent is a new and/or infrequently employed drug.
All rights reserved.

No part of this publication may be translated into other languages, reproduced or utilized in any form or by any means, electronic or mechanical, including photocopying, recording, microcopying, or by any information storage and retrieval system, without permission in writing from the publisher or in the case of photocopying, direct payment of a specified fee to the Copyright Clearance Center (see 'General Information').

(c) Copyright $2016 / 2017$ by S. Karger AG,

CH-4009 Basel (Switzerland)

Printed on acid-free and non-aging paper (ISO 9706) 